\title{
REALISM, LIBERALISM AND CONSTRUCTIVISM IN THE PURSUIT OF SECURITY
}

\author{
Lavinia-Maria Savu ${ }^{1}$ \\ National University of Political Sciences and Public Administration
}

\begin{abstract}
Security is one of the most used and disputed concepts in the field of International Relations. Achieving security has always concerned the world, from those who hunted to ensure their food security, to those who started wars in the name of self-determination. The spotlight highlighted security, especially after the two World Wars, which led to a reconfiguration of the world. The institutionalization of the field of International Relations favored the emergence of different paradigms that aimed to identify and explain the causes of the war and to develop strategies to ensure this good. The purpose of this article is to analyze three of the best-known theories - realism, liberalism and constructivism - and to highlight the methods identified in order to achieve security. The approach will be predominantly descriptive.
\end{abstract}

Keywords: security; balance of power; democracy; community security.

\section{INTRODUCTION}

The field of International Relations is a recent institutionalized one, appearing as an area of independent research in 1919 at the University of Wales. The synchronization of the emergence of this new field of research is not meaningless. The destructiveness of the First World War, labeled as total war, the high number of casualties and the effects generated underlined the importance of analyzing the causes that were at the base of such an event in order to avoid future similar catastrophes. From that moment until now, in the field of International Relations, different theories have emerged that have tried to explain why states start a conflict, what are the most important causes, but also how states can obtain and maintain a high level of security.

At that moment, the liberalist theory that appeared as an alternative to the power policy of the 19th century was best folded on the existing realities. It emerged as a natural effect of the 14 points shaped by US President Woodrow Wilson, the formation of the League of Nations and the commitment that some states have made to collective security. It turned out, not long after the end of the First World War, that the world was not yet ready to join the liberal vision - the Great Depression (1929-1933), the coming to power in Italy of Benito Mussolini, the emergence of Nazism in Germany and the seizure of power by Adolf Hitler, the expansionist desires that still incited some leaders, the inability to make the League of Nations functional and so on.

Almost 20 years later, World War II broke out giving way to a realistic vision, which was based on clear principles, derived from reality and whose arguments could be factually demonstrated (Guzzini 2000, 11). The realistic theory came to explain why the Two World Wars erupted, most of the assumptions being, in fact, a critique of liberal theory. Adherents of this current of thought explain the dynamics of international relations by appealing to the concept of power. The Cuban Missile Crisis, the Vietnam War, proxy warfare during the Cold War gave realism a proper ground in which to develop.

But as events at the international level cannot always be anticipated and out of the desire to identify alternatives, towards the middle of the Cold War a theory appears that does not seem to fit

${ }^{1}$ Corresponding author: lavinia.savu@dri.snspa.ro 
into the pattern of those so far. In the '80s we witness the drawing of the constructivist theory that comes and appeals to norms, identities and the way in which all these are co-constituted as a result of the interactions between the actors.

All three theories mentioned, but also others that arose in this field of research, tried, among other things, to explain how states can achieve security. Consequently, the aim of this article is to highlight the way in which realism, liberalism and constructivism see the attainment of a state of security. In this approach, for the scientific clarity of the paper, the first part will be intended to define the concept of security, the following three parts being aimed at exposing the strategies of the three theories on security: balance of power (realism), democratic peace theory (liberalism) and security communities (constructivism). The conclusions will be intended at synthesizing the visions of the three theories and highlighting the points of convergence.

\section{THE CONCEPT OF SECURITY - EVOLUTION AND DEFINITION}

Most of the time we have problems in defining the concepts we use most often; we know what they mean, we use them in the right contexts, but when it comes to giving a definition of them, it seems we can't find our words. This is also the case with the concept of security, which although it is one of the most used words in the field of International Relations, it is also the most controversial and difficult to define. David Baldwin stated in an article published in 1997 that "understanding the concept of security is a fundamentally different kind of intellectual exercise from specifying the conditions under which security may be achieved. Indeed, conceptual clarification logically precedes the search for the necessary conditions of security, because the identification of such conditions presupposes a concept of security" (Baldwin 1997, 8). Despite these difficulties of definition, the process must be carried out because security is a scarce commodity (Garnett 1996, 10) and extremally important for state and non-state actors.

The concept of security has evolved with the developments that have taken place in the international system, moving from traditional security to the new concept that emerged with the expansion and acquisition of new meanings.

Although it dominates the idea that the concept of security is a recent one, which took shape especially after the two World Wars, the idea of security ${ }^{2}$ is actually older than that. In the literature there is a reference to the precursors of security, among which we can mention Thomas Hobbes, Carl von Clausewitz and Thucydides. These three authors, together with others who have contributed to the extensive study of security, provided a starting point by correlating the concept with the analysis of international relations; according to Kolodziej, studying the ideas formulated by these theorists "will help us to learn how to think about security and quite a bit about what to think about security and why" (Kolodziej 2005, pp. 48-49) 3 .

The study of security has become more pronounced after the horrors that took place in the two World Wars, states becoming aware of the need to adopt policies to ensure their security. The Cold War period and consequently the study of security was mainly influenced by two theories realism and neorealism - who saw security as a central element of the state. All this time, the study of security has fluctuated, with periods of growth and decline. If the period between 1955 and 1965 is labeled as the Golden Age (Walt 1991, 212) of security study, the mid-1960s brought a drop in attention to security in the form it had.

The vision that dominated the Cold War period is the traditional one, the emphasis being mainly on military components and the role they play in achieving security. In the anarchic ${ }^{4}$ context that characterized the international system, the state - which was seen as the key player - had to pursue its national interests "defined in terms of power" (Morgenthau 1948). The most appropriate tools, according to realists and neo-realists, to achieve their security objectives in an unsecured world are those in the military spectrum. Distrust in the intentions of states leads actors to resort to violent

\footnotetext{
${ }^{2}$ Regarding the writings of the forerunners, a distinction must be made between idea and concept. In the writings of the precursors, we do not identify per se the term security, but ideas that correspond to what later received the name of security.

${ }^{3}$ More details about the contributions of these precursors can be found in the cited work of Edward A. Kolodziej.

${ }^{4}$ Anarchy must be understood as the lack of a central government, of an authority and not as a state of chaos.
} 
means to resolve disputes. Consequently, in this context dominated by the realistic vision, the definitions offered to the concept of security fall within the mentioned parameters. In the first edition of the journal International Security, published in 1976, security was described as an element that has a "direct bearing on the structure of the nation state system and the sovereignty of its members, with particular emphasis on the use, threat and control of force" (Carnesale and Nacht 1976, 2). A definition which even if it falls within the framework of the realistic theory brings a new dimension is the one formulated by Arnold Wolfers who distinguishes between subjective and objective security: "security, in an objective sense, measures the absence of threats to acquired values, in a subjective sense, the absence of fear that such values will be attacked" (Wolfers 1952, 485).

The fall of the Iron Curtain, the implosion of the Soviet Union on the background of socioeconomic shortcomings, the exit from the communist wing of Central and Eastern European states and the diversification of actors are some of the elements that underlined the complexity of the postCold War world. In the newly created context, security strictly understood in military terms could no longer find its place. Threats have begun to diversify, becoming transnational, cross-sectoral and interdependent. It has been noted that developments in one sector have effects in other areas, and the approach to security needs to be integrated. Those who understood these needs led the process of expanding security; the approach attracted new followers, the result being a multidimensional security concept.

The pioneers of the expansion are the representatives of the Copenhagen School, led by Barry Buzan. One of the first works in which the need to expand the study of security was exposed is Peoples, States and Fear, which adds four other types of security to the military one - political, societal, economic and environmental (Buzan 2014). In order to understand security, we need to answer a few basic questions: "What is to be protected?" - security reference object; "Against which threats is the object of reference protected?" (Buzan 2014, 26). In this approach, Buzan detaches himself from the traditional perspective and shows that the object of reference is not only the state, but also the international system and the individual and that the threats come from all five sectors mentioned above. Moreover, the new approach sought to establish a set of criteria to distinguish between security issues and those that do not fall within this spectrum (Buzan, Waever and de Wilde 1998, 5).

Against this background, the expansion of the concept of security was achieved both vertically through the emergence of new forms, such as individual security and human security, and horizontally by including the political, military, economic, societal and environmental sectors. Now, when we talk about security, the military side is no longer the one that dominates, the concept is described as a multidimensional one, the goal being to ensure the well-being and safety of international actors.

\section{REALISM AND THE BALANCE OF POWER}

Realism is one of the theories of International Relations that has dedicated its study to identifying methods to ensure the survival of the state and consequently its security. Two papers formed the basis of the development of realistic theory - Hans J. Morgenthau's Politics among Nations and The Twenty Years' Crisis 1919-1939 written by Edward. H. Carr. However, Morgenthau's book, described as the leading work of international political theory (Thompson and Clinton 2013, 15), had the greatest influence on the development of realism.

Like other currents of thought, realism has a number of key assumptions and concepts that help us understand the essence of this theory. In a simplified version, realistic theory "is a school of thought that explains international relations in terms of power" (Pevehouse and Goldstein 2017, 38). One of the main assumptions of this theory is that the key player in the international system is the state; adherents of realism do not deny the importance of other actors, such as transnational companies, but consider their role to be limited. The state, that is a rational actor, has a number of national interests which, as we have already mentioned, it defines in terms of power. The concept of power ${ }^{5}$ is a central one in the realistic thesis, the most praised form being the military one. The

\footnotetext{
${ }^{5}$ The simplest definition of power is the ability of a state A to cause a state B to do something it would not normally do.
} 
second edifying assumption refers to the international system which is anarchic; proponents of the theory speak of the lack of a central government. This international context allows states to pursue their national interests (Miroiu and Soare 2006, 99). A third assumption refers to human nature which is vitiated, entangled in the struggle for power and unchanging.

Uniting these three main assumptions ${ }^{6}$, we see that states are entering a vicious circle in search of survival. Because one of the aims of the emergence of realism was precisely the attempt to explain why wars are started and how these rational actors can ensure their security, within the realistic theory a strategy was drawn in this regard - the balance of power. This strategy has been praised by various academics in the field of International Relations, with some considering that "no other proposal on international politics has attracted more effort from scholars than the balance of power. It is perhaps as essential in today's thinking as it has been at any time since the Enlightenment" (Brooks and Wohlforth 2008, 7). Being such an important concept, its explanation has crossed the boundaries of realism and neo-realism, coming to be analyzed by other theories ${ }^{7}$.

The central thesis of the balance of power is that states try to survive as independent entities (Paul, Wirtz and Fortmann 2004, 4); if a state is growing, endangering other actors in the international system, other smaller states will see this state as a threat and will seek solutions to balance the power displayed by the first actor. The father of realism, Hans Morgenthau, considers that the balance of power and policies aimed at establishing and maintaining balance are crucial for the stability of the international system (Andersen 2018, 8). He conceptualizes the balance of power as a natural and inevitable extension of the struggle for power, a state of affairs in which power is evenly distributed among nations.

In Morgenthau's conception there are two types of balance of power - the direct opposition model and the competition model - each highlighting a set of functions. The model of direct opposition presupposes the existence of two states or alliances that enter into a direct confrontation: actor $X$ has imperialist aspirations, and actor $Y$ reacts through a strategy of preserving the status quo or through an imperialist policy (Morgenthau 1948, 130). In this case, the balance of power is the direct result of the decision of both actors to follow their policies, noting that the resulting balance is fragile. The second model, that of the competition, involves the appearance of a third actor - Z. State $X$ can pursue an imperialist policy in relation to state $Z$, and state $Y$ can respond either by adopting a status quo policy or an imperialist one. The strategies of state $Z$ can be: balancing the state pursuing an imperialist policy $(X)$, which means that it will ally with state $Y$, or alignment with the source of danger (bandwagoning), more precisely with $X$. The function of the balance of power in this case is the independence of state Z (Morgenthau 1948, 133). In Morgenthau's view, the balance of power has several meanings, but the most commonly used by the is the situation when the weights on both plates of a scale are balanced (Little 2007, 95).

Kenneth Waltz, the representative of neo-realism, praises the balance of power and says it is an independent theory of international politics (Waltz 1979, 167). His theory is animated by the principle of small numbers and assumes that the structure of the international system is defined by a limited number of large powers. Waltz linked the concept of the balance of power with two elements: i) anarchy, in the sense that the appearance of balance is a direct result of the structure of the international system, and ii) the assumption that states are rational actors trying to maintain their position in the international system, balancing with a growing power becoming inevitable (Diez, Bode and Da Costa 2011, 8). In this logic, Waltz's central point is that the anarchic structure constrains the behavior of states (concerned with survival) in such a way as to seek the balance of power; for the author it does not matter if the states are revisionist or status quo, because they will be influenced by the structure of the system to promote policies to seek balance (Little 2007, 193). In anarchic systems, Waltz states that balancing and not aligning is a typical behavior (Waltz 1979, 126).

Between bipolarity and multipolarity, Waltz believes that the most appropriate type of structure that favors the balance of power is bipolarity. With only two great powers, the chances of them misperceiving each other's relative strength are low, as they are able to learn how to interpret each

\footnotetext{
${ }^{6}$ The assumptions of realistic theory are not limited to the three set out in this article, but they are most often invoked.

${ }^{7}$ An example is the analysis made by Hedley Bull, representative of the English School.
} 
other's movements. The Cold War was a favorable period that confirmed most of the assumptions put forward by the followers of realism, whether we are talking about the classical or the structural (neorealism).

Morgenthau and Waltz are not the only ones who have approached the concept of balance of power, in the field of International Relations being several academics who have dedicated their study to explaining and understanding how balance works at the international level. ${ }^{8}$

Security in the realistic vision is essential for the survival of the main actors - the states, and can be achieved through the use of military instruments. In terms of the balance of power, this strategy creates a favorable framework in which the security of states can be achieved. Depending on the chosen options, the security can be fragile or durable.

\section{DEMOCRATIC PEACE THEORY - A STRATEGY OF LIBERAL THEORY}

Liberalism is next to realism, one of the most important theories of International Relations, which from the beginning has turned its attention to how war can be eradicated, and international actors can identify peaceful methods of resolving disputes. Liberalism as a theory of International Relations did not emerge from nothing, but has its roots in the works of Immanuel Kant, John S. Mill, Richard Cobden, Woodrow Wilson and other philosophers and thinkers who elaborated papers that later stood at the basis for outlining the main ideas of the theory which is under analysis in this part. Two examples of ideas that were taken over by liberal theory are those formulated by Kant and Cobden: i) Kant advocates the privilege of democracy as an alternative principle of governance primarily internal, but also external, which later contributed to the formulation of the theory of democratic peace; ii) Cobden talks about economics, arguing that the only policy of peace is free trade that leads to economic prosperity, his ideas being contained in what is called the theory of economic interdependence.

The traumatic experience of the First World War led to the modeling of an alternative of liberal origin to the power policy of the nineteenth century, accused of irrationality (Biro 2006, 82). Like other theories, liberalism starts from a set of key assumptions, some of which are in direct opposition to those of realistic theory. Firstly, the liberals' view of human nature refers to the belief in the perfectibility of the human condition as a result of intellectual capacity and confidence in the possibility of progressive evolution (Biro 2006, 89). Secondly, peace is a state of affairs and not the struggle for power, as the representatives of realism claim. Scott Burchill points out that liberalism sees war as a cancer of the political body, something that belongs to the realm of the abnormal (Burchill 2013, 61). Within the liberal school, various ideas emerged that emphasized how peace can be achieved - from the adoption of democracy as a principle of government and the benefits generated by economic relations, to the establishment of international institutions that have the necessary strength to contribute to the harmonization of state interests. Thirdly, the main actors are no longer the states, but the individuals whose security and well-being must be ensured. It is on this basis that liberals are seen as some of the most ardent supporters and promoters of human rights. Fourthly, the followers of this current of thought believe that the actors can cooperate with each other, even taking a harmonization of interests. Such an approach is supported in particular by the creation of international institutions and bodies that generate a framework conducive to collaboration. Last but not least, a central element of the liberalist thesis is the principle of collective security which assumes that states are aware that the security of one of them concerns them all and are willing to react to any threat. This is also the principle we find in Article 5 of the North Atlantic Treaty.

As I already mentioned, in liberalism we find several strategies developed to eradicate war as a mean of resolving disputes and to ensure the security of actors - institutional liberalism (emphasizes the importance of international institutions), the theory of economic interdependence (praises the benefits of economic interactions that take place between actors), the theory of democratic peace (directs its attention to the form of government) and so on. In the following I will turn my attention to the theory of democratic peace, being one of the most often invoked, but also criticized theories.

\footnotetext{
${ }^{8}$ In order to deepen the subject, I recommend consulting the works elaborated by Hedley Bull and John Mearsheimer.
} 
The leading work that has significantly contributed to the development of the theory of democratic peace is Perpetual Peace written by Immanuel Kant. Kant's argument for obtaining perpetual peace is that three definitive articles must be enforced: i) the first article refers to the form of organization of the state that must be a republic; ii) the second article presupposes the creation of a pacifist federation or union, resulting from the will of each state; iii) the third article represents a cosmopolitan law that must be limited to the conditions of general hospitality (Doyle 1986, 1158).

In the twentieth century, the number of researches that talked about the benefits that democracy can generate has increased considerably, becoming a recurring topic of International Relations; it can be identified on the international agenda especially after the Second World War and to the present day. The most representative figures of the twentieth century in the approach to democratic peace are Rudolph Rummel and Michael Doyle. The approaches of the mentioned researchers are in the lines of two versions of democratic peace - the monadic version and the dyadic one. The monadic or general version supports the idea of a general pacifism of democracies, regardless of the nature of the opponents, while the dyadic version (also called relational) refers to a state of peace that exists between democracies, noting that in relation to non-democratic actors they can resort to violent means, including war (Biro, Teza pacifismului democrat 2006, 260).

One of the books written by Rummel in support of the idea that democracies contribute to a state of peace and security is Power Kills: Democracy as a method of nonviolence. From the introductory part of the paper, Rummel sets out the main motivation for which he carried out research aimed at reducing war in all its forms: "(...) in the mid-1980s I was shocked to discover that several times more people were killed in democide ${ }^{9}$ by governments than died in warfare. (...) I believe, I can finally offer what appears a most realistic and practical solution to war, democide, and other collective violence" (Rummel 1997, ix).

The paper, written in 1997 and which is the result of years of work, has as its central thesis the idea that the worst types of violence, such as mass murder, are the result of the tyrannical nature of governments that commit such crimes. Thus, the elimination of democide can take place by promoting and strengthening democratic governance (Chenoweth 2017, 101). In support of his thesis, Rummel makes a number of arguments, including that democracy is in a continuous, dynamic flow and encompasses social fields, while authoritarianism is static, rigid, generating social cleavages that push people to resort to violence to survive. He believes that the reduction of violence by democracy is gradual and that although some problems remain, this form of government offers the best response to the needs of a stable society (Chenoweth 2017, 102).

A second contribution that attracted attention thanks to the clearly stated ideas is that of Michael Doyle; his name is directly associated with the theory of democratic peace. Doyle's main idea is that states that adhere to liberal principles enjoy the benefits of a separate peace in relation to states that share the same principles, but are predisposed to start a war against non-liberal states; it follows that his version falls into the dyadic one. In his approach, Doyle took into account three areas that contribute to a high degree to the call for peaceful solutions in relations between democracies the political/institutional, social and economic. The institutional element is an essential one considering two characteristics of democracy - representation and transparency (Doyle 2012, 215). In addition to the benefits they generate for society, they send a message to external partners that the risk of unforeseen actions is low. Moreover, following broadly the same principles, in this case liberal ones, states can intuit what the other's movements would be. Also, from a political point of view, the election system, the rotation of elites and the division of power can also send signals, making a possible desire to resort to war predictable. In addition, the outbreak of war by a democracy is a more complicated process, due to the bureaucracy and control tools that exist, than in an autocratic society; in short, the existence of the checks and balance system decreases the chances of starting a war.

From a social point of view, individuals living in such societies have a wide range of tools at their disposal to control the activities of the chosen ones, from petitions to rallies. Last but not least,

\footnotetext{
${ }^{9}$ Democide is defined by Rummel as mass murder that includes four subcategories: terror, genocide, mass murder, and politicide (politically killing a group).
} 
the economic level provides the impetus for increased cooperation between democracies, which are based on the market economy and seek the development of economic relations.

The whirlwind that this theory created attracted, without a doubt, a high number of critics, the contestants demanding clear evidence. They cite those situations when even democracies resorted to war to resolve their disputes, an example being the war between the United States and Spain in 1898. Another criticism concerns the exclusion by supporters of democratic peace of other arguments that could justify the state of security that arises.

In the view of liberalism, security is a state of affairs that can be achieved through cooperation and the harmonization of interests. The main beneficiaries of this condition are individuals. The theory of democratic peace, described as a theory that has the necessary force to ensure the security of actors, is based on the ideas, institutions and mechanisms developed by democracy. Notwithstanding, we must not forget the statement of Doyle and other researchers who specified that the adoption of democracy does not directly produce a state of peace, but increases the level of security and stability.

\section{SECURITY COMMUNITIES - A CONSTRUCTIVIST PERSPECTIVE}

If the two theories can be labeled as traditional, in the 80 's, in the field of International Relations, a paradigm emerged that tried to meet the needs of the world at that time - constructivism. The approach managed to overcome the existing barriers and based its argument on norms, language, identity and interaction. We can enumerate Alexander Wendt, Nicholas Onuf, Friedrich Kratochwil as outstanding figures who built their arguments with the help of the stated variables. Onuf is one of the first to use the term constructivism in the field of International Relations, arguing that we live in a "world of our making" (Onuf 2012), while Wendt is famous for the statement "anarchy is what states make of it" (Wendt 1992).

The main question that also arises in the case of constructivist theory is the extent to which it manages to explain the behavior of states in terms of security. Constructivists come up with a new approach in which they believe that the predominant theories are wrong and have the potential to mislead states in developing security policies (Kolodziej 2005, 259).

The starting point of the constructivist paradigm is the interaction between actors which is seen as a determinant of their behavior and identities. Specifically, agencies ${ }^{10}$ and structures are coconstituted, meaning that the former produce structures through beliefs, actions, and interactions between them, and the forms created play an important role in shaping identities and interests. Hence the argument that the state is not a given, but is a social construct, which may have different interests depending on the identities at a given time. To better understand this statement, we can think of Germany, which during the Nazis defined its national interests in revisionist terms, somehow encouraged by its relations with other states that rallied to these interests (see Italy), but which, with the transition to a new paradigm and obtaining UN membership, has also changed its national interests. Along the same lines is the assumption that the international system is a social creation as a whole.

A second important point of this paradigm is that material factors mean nothing in the absence of complex social processes that give them meaning (Wendt, Constructing International Politics 1995, 73). States decide what they want not only on the ground of material needs, but also on the basis of social interactions, noting that constructivists recognized that power is not absent from international relations (Pevehouse și Goldstein 2017, 92). The most common example is why the US is more concerned with the construction of a nuclear weapon by North Korea, and not by United Kingdom. To answer this dilemma, constructivists come and emphasize the shared common history, common norms, the alliances to which the two actors have been part over time; these variables send a message to the US and the UK, showing them that they are not a threat to each other, which is not the case with North Korea. Thus, the presence of material factors (nuclear weapons), according to the

\footnotetext{
${ }^{10}$ Agents are international actors.
} 
realists, should have caused the two states to confront each other from positions of power. Instead, the identity of the potential opponent weighed more in relation to the material elements.

This brings us to a third point, namely that of the norms and rules. Norms constitute social identities and give meaning to national interests (Adler, Constructivism in International Relations: Sources, Contributions and Debates 2013, 126). Katzenstein pointed out in a 1996 paper that states make security choices and act not only in the context of physical capabilities, but also on the basis of normative agreements. Going beyond the internal framework, Martha Finnemore said that international norms formulated by international organizations, contribute to a significant degree to shaping the interests of the states that adopt them (Finnemore 1996, pp. 5-13).

Last but not least, the constructivists and especially Onuf questioned the importance of language and speech acts. In addition to social interactions, language comes and assigns a certain meaning, depending on the context. In the absence of discourse and language, international reality does not exist and cannot be communicated, Kratochwill emphasizing that speech acts are means of constructing intersubjective meanings (Toderean 2006,161).

In the process of developing the role of identity, Emanuel Adler and Michael Barnett have shown that the identities of national groups can transcend borders and lead to the development of security communities. Although this concept is not an eminently constructivist intellectual product, it has been best explained by followers of this paradigm. In their approach, they turned to the vision of Karl Deutsch, who argued that those states that are part of a security community have created not only a stable order, but also a stable peace (Adler și Barnett 1998, 3). In his approach, Deutsch distinguished between amalgamated and pluralistic security communities. While both create reliable expectations for peaceful change, the former exists when states formally unify, and the latter when states retain their sovereignty. To better understand the two examples, we can look at the US which is from the author's point of view an amalgamated security community model, while the European Union falls within the parameters of the second version. The Deutschian vision considers that security communities appear thanks to a high degree of integration, a degree that is achieved with i) obtaining a sense of community, ii) developing practices and institutions and iii) a high level of transactions (Ditrych 2014, 351). Although Deutsch's approach was innovative for the period in which it was treated (1957), when power was the dominant concept, it was unsuccessful.

The idea of security communities came to life with the end of the Cold War, a time when the assumptions postulated by Deutsch 40 years ago seemed again relevant amid changes in global policy. With the end of the Cold War, the discourse of decision-makers has changed, and they are now talking about plans for a more peaceful and stable international order. This was to be expected, with the end of wars almost always spurring comments about the world that is left behind and hopeful speculation (Adler și Barnett, Security communities in theoretical perspective 1998, 4).

In this new context, Adler and Barnett decided to revitalize the security communities, focusing on the pluralistic ones. They started with the idea that such a community exists at the international level, that power policy is deeply shaped by it and that those states that live within the international community could develop a pacifist disposition (Adler și Barnett 1998, 3). The pluralistic communities developed by the two are defined as those transnational regions made up of sovereign states whose people maintain reliable expectations of peaceful change (Adler și Barnett 1998, 30).

Adler and Barnett divide the pluralist security communities according to the depth of trust, the nature and the degree of institutionalization of the system of government and whether they are in a formal anarchy or are about to transform it. Depending on these three criteria, loosely and tightly coupled pluralistic security communities may emerge (Adler and Barnett 1998, 30). The working method is organized on three levels, representing the steps taken in creating a security community (Adler and Barnett 1998, pp. 37-45):

1. Against the background of endogenous and exogenous factors, states begin to orient and coordinate with each other. Elements such as an external threat or technological development can drive states to form alliances, thus seeking to reduce fear through security coordination. These meetings and acts of cooperation do not automatically produce trust, but are essential steps in the development of complexes. 
2. Once states began to engage in various forms of social interaction, the environment in which they live began to change. From this moment, forms of collective identity and mutual trust can appear, elements necessary for a peaceful development.

3. The dynamic and positive relationships that take place over time become sources of mutual trust and the development of collective identity.

The main contribution generated by the development of security communities is that it has opened up the possibility of thinking in terms of community in the international space (Bellamy 2004, 5).

The inclusion of the security community formula in the discourses of international and regional organizations (see the case of ASEAN) shows the commitment that these institutionalized forms are beginning to have towards the concept presented in this part.

The constructivist paradigm has brought a relatively new vision of security. Obtaining it is a process that includes the interaction between actors and structures, common cultural elements, historical elements, the process of creating norms and assuming them, and so on. One of the constructivist strategies through which this can materialize is security communities. The constant interaction between the actors creates the premises for increasing the relationship and trust, thus decreasing the chances of differences. Therefore, the actors manage to ensure their own security.

\section{CONCLUSIONS}

The purpose of this article was that through this supple exposition to be highlighted the ways in which three of the most well-known paradigms of International Relations see the obtaining of security. The main conclusion is that all three are concerned with identifying the causes of the war and developing strategies to ensure the security of international actors. Firstly, when the balance of power appears no state predominates and therefore no large-scale war will take place. The result is a stable international system, even if there are chances of changes in the balance of power (these do not fundamentally affect the balance). Secondly, the theory of democratic peace bases its study on the mechanisms that exist in these societies and that determine a reluctance to adopt war as a tool for resolving disputes. In this sense, there are data that support this theory, in the idea that it fails to completely eradicate the war, but decreases the chances of triggering. Thirdly, the solution proposed by the constructivists emphasizes rules, identities and language seen as essential elements in the formation of security communities. Identifying with other members of the community and the interactions that lead to the creation of a collective identity, increase the chances of peaceful settlement of disputes. In this way, the actors involved in such forms of coexistence would benefit from security.

As we can observe, the security differences between the three lies in the emphasis they placed on various elements; for example, while realism praised the importance of power, liberalism rather highlighted the beneficial effects of respect for human rights, the rule of law, and so on. However, there are also points of convergence - the formation of security communities may be similar up to a point with the theory of institutional liberalism and the variant proposed by Deutsch with the theory of economic interdependence.

The main ideas of realism, liberalism and constructivism were summarized in the table below, in order to give the reader an overview.

Table 1. The main ideas of realism, liberalism and constructivism

\begin{tabular}{|c|c|c|c|}
\hline Features & Realism & Liberalism & Constructivism \\
\hline $\begin{array}{c}\text { Nature of the } \\
\text { international system }\end{array}$ & $\begin{array}{c}\text { Anarchic } \\
\text { The struggle for power }\end{array}$ & $\begin{array}{l}\text { Formal anarchy with } \\
\text { interdependence } \\
\text { Shared norms and } \\
\text { international institutions }\end{array}$ & Socially constructed \\
\hline Relevant actors & States & $\begin{array}{c}\text { Non-state actors (people, } \\
\text { international organizations), } \\
\text { but also states }\end{array}$ & $\begin{array}{l}\text { States, organizations, } \\
\text { people, ideas }\end{array}$ \\
\hline Key assumptions & $\begin{array}{l}\text { - power is the main } \\
\text { concept, with a special }\end{array}$ & $\begin{array}{l}\text { - the well-being of the } \\
\text { individual; }\end{array}$ & $\begin{array}{l}\text { - agencies and structures } \\
\text { are co-constituted; }\end{array}$ \\
\hline
\end{tabular}




\begin{tabular}{|c|c|c|c|}
\hline Features & Realism & Liberalism & Constructivism \\
\hline & $\begin{array}{c}\text { focus on the military } \\
\text { one; } \\
\text { - human nature is } \\
\text { flawed; } \\
\text { - states seek survival; } \\
\text { - national interests } \\
\text { dominate; } \\
\text { - states cannot trust the } \\
\text { intentions of other } \\
\text { actors; }\end{array}$ & $\begin{array}{l}\text { - human nature is } \\
\text { perfectible; } \\
\text { - collective security; } \\
\text { - the importance of } \\
\text { international } \\
\text { institutions; } \\
\text { - harmonization of } \\
\text { interests; } \\
\text { - cooperation is possible; }\end{array}$ & $\begin{array}{l}\text { - the meanings we } \\
\text { attribute to the social } \\
\text { world result from the } \\
\text { interactions of agents; } \\
\text { - material factors mean } \\
\text { nothing in the absence } \\
\text { of complex social } \\
\text { processes that give } \\
\text { them meaning; } \\
\text { - international structures, } \\
\text { processes and actors } \\
\text { are social products; }\end{array}$ \\
\hline Security & $\begin{array}{l}\text { It can be obtained by } \\
\text { using military instruments }\end{array}$ & $\begin{array}{l}\text { Cooperation and } \\
\text { harmonization of interests } \\
\text { increase the chances of } \\
\text { achieving and maintaining } \\
\text { a state of security }\end{array}$ & $\begin{array}{l}\text { Frequent contacts, } \\
\text { common cultural } \\
\text { elements, good } \\
\text { historical relations } \\
\text { and norms are } \\
\text { relevant for security }\end{array}$ \\
\hline $\begin{array}{c}\text { Strategies of achieving } \\
\text { security }\end{array}$ & Balance of power & Democratic peace theory & Security communities \\
\hline
\end{tabular}

It should be mentioned that the stated strategies are not the only ones formulated, but they are some of the most known, studied and applied.

\section{REFERENCES}

Adler, Emanuel. 2013. "Constructivism in International Relations: Sources, Contributions and Debates." In Handbook of International Relations, de Walter Carlsnaes, Thomas Risse and Beth A. Simmons, 112-144. Los Angeles, Londra: Sage.

Adler, Emanuel, and Michael Barnett. 1998. "A framework for the study of security communities." In Security communities, Emanuel Adler and Michael Barnett, 29-65. Cambridge: Cambridge University Press.

Adler, Emanuel, and Michael Barnett. 1998. "Security communities in theoretical perspective". In Security Communities, Emanuel Adler and Michael Barnett, 3-28. Cambridge: Cambridge University Press,.

Andersen, Morten Skumsrud. 2018. "Balance of Power", John Wiley \& Sons: 1-12.

Baldwin, David. 1997. "The concept of security". Review of International Studies 23, no. 5: 5-26.

Bellamy, Alex J. 2004. Security Communities and Their Neighbours. Regional Fortresses or Global Integrators? Hampshire, New York: Palgrave Macmillan.

Biro, Daniel. 2006. "Idealismul utopic" sau gândirea internaționaliștilor liberali In perioada interbelică". In Manual de Relații Internaționale, Adrian Miroiu and Radu-Sebastian Ungureanu, 77-93. Iași: Polirom.

Biro, Daniel. 2006. "Teza pacifismului democrat". In Manual de Relații Internaționale, Andrei Miroiu and Radu-Sebastian Ungureanu, 257-271. Iași: Polirom.

Brooks, Stephen G., and William C. Wohlforth. 2008. World Out of Balance: International Relations and the Challenge of American Primacy. Princeton: Princeton University Press.

Burchill, Scott. 2005. "Liberalism". In Theories of International Relations, Third Edition, Scott Burchill, and all, 55-83. New York: Palgrave Macmillan.

Buzan, Barry. 2014. Popoarele, statele and frica. Ediția a II-a. Chișinău: Cartier. 
Buzan, Barry, Ole Waever, and Jaap de Wilde. 1998. Security. A new framework for analysis. Colorado: Lynne Rienner Publishers.

Carnesale, Albert, and Michael Nacht. 1976. "International Security" 1, no. 1.

Chenoweth, Erica. 2017. "Democracy as a Method of Nonviolence." In R.J. Rummel: An Assessment of His Many Contributions, Nils Petter Gleditsch, 101-109. Oslo: Peace Research Institute Oslo.

Diez, Thomas, Ingvild Bode, and Aleksandra Fernandes Da Costa. 2011. Key Concepts in International Relations. Los Angeles, Londra: Sage.

Ditrych, Ondrej. 2014. "Security community: A future for a troubled concept?". International Relations 28, no. 3: 350-366.

Doyle, Michael. 1986. "Liberalism and World Politics." The American Political Science 80, no. 4: 1151-1169.

Doyle, Michael W. 2012. Liberal Peace. Selected essays. London, New York: Routledge.

Finnemore, Martha. 1996. National Interests in International Society. Ithaca: Cornell University Press.

Garnett, J.C. 1996. "Introduction: Conflict and Security in the new world order". Security Issues in the Post-Cold War.

Guzzini, Stefano. 2000. Realism and relații internaționale. Iasi: Institutul European.

Kolodziej, Edward A. 2005. Security and International Relations. New York: Cambridge University Press.

Little, Richard. 2007. The Balance of Power in International Relations: Metaphors, Myths and Models. New York, Cambridge: Cambridge University Press.

Miroiu, Adrian, and Simona Soare. 2006. "Realism". In Manual de Relații Internaționale, Adrian Miroiu and Radu-Sebastian Ungureanu, 95-104. Iași: Polirom.

Morgenthau, Hans J. 1948. Politics among nations. The struggle for power and peace. New York: Alfred A. Knopf.

Onuf, Nicholas Greenwood. 2012. World of our making: Rules and rule in social theory and international relations. Londra, New York: Routledge.

Paul, T. V., James J. Wirtz, and Michel Fortmann. 2004. Balance of power. Theory and Practice in the 21st Century. California: Stanford University Press.

Pevehouse, Jon C. W., and Joshua S. Goldstein. 2017. International Relations. Brief Seventh Edition. Washington: Pearson.

Rummel, Rudolph. 1997. Power Kills: Democracy as a method of nonviolence. New Brunswick, Londra: Transaction Publishers.

Thompson, Kenneth W, and David W. Clinton. 2013. In Politica între națiuni. Lupta pentru putere și lupta pentru pace, Hans Morgenthau. Iași: Polirom.

Toderean, Olivia. 2006. "Constructivismul In Relațiile Internaționale". In Manual de Relații Internaționale, Andrei Miroiu and Radu-Sebastian Ungureanu, 155-164. Iași: Polirom.

Walt, Stephan M. 1991. "The Renaissance of Security Studies". International Studies Quarterly 35, no. 2: 211-239. 
Waltz, Kenneth N. 1979. Theory of International Politics. Massachusetts: Addison-Wesley Publishing Company.

Wendt, Alexander. 1992. "Anarchy is what States Make of it: The Social Construction of Power Politics". International Organization 46, no. 2: 391-425.

Wendt, Alexander. 1995. "Constructing International Politics". International Security 2-1: 71-81.

Wolfers, Arnold. 1952. "National Security as an Ambiguous Symbol". Political Science Quarterly (The Academy of Political Science) 67, no. 4: 481-502. 